\title{
PENGARUH MODEL DISCOVERY LEARNING BERBASIS HIGHER ORDER THINKING SKILL TERHADAP KEMAMPUAN BERPIKIR KRITIS
}

\author{
Diyas Age Larasati \\ Bahasa dan Sains, Universitas Wijaya Kusuma Surabaya \\ Email: larasati_age@yahoo.co.id
}

INFO ARTIKEL
$\begin{aligned} & \text { Riwayat Artikel: } \\ & \text { Menerima }\end{aligned}$
$\begin{array}{ll}\text { Revisi } & : 23 \text { April } 2020 \\ \text { Diterima } & : 24 \text { April } 2020 \\ \end{array}$

Kata Kunci:

Discovery Learning, Higher Order Thinking Skill, Berpikir kritis

\section{Keywords:}

Discovery Learning, Higher Order Thinking Skill, Critical Thinking

\section{Korespondensi:}

Diyas Age Larasati Bahasa dan Sains, Universitas Wijaya Kusuma Surabaya Email:

larasati_age@yahoo.co.id

\section{ABSTRAK}

Pembelajaran IPS SD menjadi pembelajaran yang membosankan, karena guru belum menerapkan model, metode, strategi pembelajaran yang inovatif. Guru juga hanya melatih siswa untuk hafalan-hafalan konsep IPS, belum melatih berpikir kritis. Discovery learning sebagai salah satu model pembelajaran memiliki keunggulan mengaktifkan siswa. Tujuan penelitian ini untuk mengetahui pengaruh model discovery learning berbasis higher order thinking skill terhadap kemampan berpikir kritis. Penelitian ini berjenis eksperimen semu, dengan rancangan Non Equivalent Control Group Design. Kelas eksperimen menerapkan model discovery learning berbasis Higher Order Thinking Skill, sedangkan kelas kontrol menerapkan model penugasan dan diskusi berbasis Higher Order Thinking Skill. Penelitian ini menggunakan populasi kelas V SDN Banyu Urip IX Surabaya. Dua kelas dipilih secara random sampling sebagai sampel penelitian. Kelas V-A berjumlah 32 siswa sebagai kelas eksperimen. Kelas V-B berjumlah 30 siswa sebagai kelas kontrol. Intrumen penelitian ini menggunakan soal (pretest dan posttest) dalam bentuk essai berjumlah 4 butir soal. Teknik pengumpulan data menggunakan penskoran terhadap hasil pretest dan posttest. Uji T digunakan untuk menguji hasil data penelitian. Hasil data penelitian menunjukkan rata-rata gainscore kelas eksperimen sebesar 5,75 lebih tinggi daripada kelas kontrol sebesar 2,6. Hasil data yang menggunakan uji-t. Hal ini dapat dilihat dari nilai $t=7,986$ dan signifikansi dua ekor 0,000 , sehingga $\mathrm{p}<0,05$. Hal tersebut membuktikan bahwa terdapat pengaruh model discovery learning berbasis higher order thinking skill terhadap kemampan berpikir kritis.

\section{ABSTRACT}

Elementary school social studies learning becomes boring learning, because teachers have not applied innovative models, methods, and learning strategies. The teacher also only trains students to memorize social science concepts, not to train critical thinking. Discovery learning as one of the learning models has the advantage of activating students. The purpose of this study was to determine the effect of discovery learning models based on higher order thinking skills on critical thinking skills. This research is a quasi-experimental type, with a Non Equivalent Control Group Design. The experimental class applies the discovery learning model based on the Higher Order Thinking Skill, while the control class applies the assignment and discussion model based on the Higher Order Thinking Skill. This study uses a population of class V SDN Banyu Urip IX Surabaya. Two classes were chosen by random sampling as a research sample. Class V-A numbered 32 students as an experimental class. Class V-B totaling 30 students as a control class. The instruments of this study used 4 questions (pretest and posttest) in the form of essays. Data collection techniques used scoring of the results of the pretest and posttest. T test is used to test the results of research data. The results of the research data show that the average gaincore of the experimental class was 5.75 higher than the control class of 2.6. The results of data using the t-test. This can be seen from the value of $t=7.986$ and the significance of two tails is 0.000 , so that $p<0.05$. This proves that there is an influence of discovery learning model based on higher order thinking skills on critical thinking skills.

(c)2020 LPPM STKIP PersadaKhatulistiwa Sintang 


\section{PENDAHULUAN}

Pembelajaran yang efektif didukung oleh pemilihan model, metode, dan media yang digunakan guru. Sejalan dengan Sari, (2014) guru harus cermat dalam memilih model pembelajaran dan merancang program serta strategi pembelajaran, sehingga pembelajaran yang dilakukannya menjadi pembelajaran yang menarik, aktual, dan fungsional bagi siswa. Pemilihan dan penerapan model, metode, dan media pembelajaran berdampak pada tercapainya tujuan pembelajaran.

\section{Suprihatiningrum}

mengemukakan bahwa model pembelajaran merupakan suatu rancangan yang di dalamnya menggambarkan sebuah proses pembelajaran yang dapat dilaksanakan oleh guru dalam mentransfer pengetahuan maupun nilai-nilai kepada siswa. Model pembelajaran berisi sintak-sintak yang diterapkan guru dalam pembelajaran guna tercapainya tujuan pembelajaran. Guru dituntut untuk kreatif mengembangkan model pembelajaran agar siswa merasa senang dan aktif ketika belajar. Pengembangan model-model pembelajaran merupakan suatu keharusan yang dilakukan oleh guru dalam kegiatan pembelajaran (Sore, 2015). Model pembelajaran yang dapat mengaktifkan siswa diantaranya yaitu model discovery learning.

Discovery learning melibatkan peserta didik secara langsung, agar peserta didik dapat menemukan tujuan dari suatu pembelajaran dengan cara mengamati, memecahkan masalah, berdiskusi bersama peserta didik yang lain dan guru hanya membimbing dan memberikan intruksi (Muslihudin, 2019) Discovery learning dikembangkan berdasarkan pandangan konstruktivisme. Model ini menekankan pada pentingnya pemahaman terhadap suatu konsep dalam pembelajaran melalui keterlibatan siswa secara aktif dalam proses pembelajaran.

Discovery learning dikembangkan sebagai cara belajar siswa aktif dengan menemukan sendiri, menyelidiki sendiri, maka hasil yang diperoleh akan setia dan tahan lama dalam ingatan, tidak akan mudah dilupakan oleh siswa. Melalui belajar penemuan, anak juga bisa berfikir lebih kritis dan mencoba memecahkan sendiri masalah yang dihadapi (Kristin, 2016).

Adapun sintaks model discovery learning menurut Syah (dalam Yudi Cahyo Winoto, 2020), yaitu: (1) stimulation atau pemberian rangsangan, (2) problem statement atau identifikasi masalah, (3) data collection atau pengumpulan data, (4) data processing atau pengolahan data, (5) verification atau pembuktian, (6) generalization atau menarik kesimpulan. Tahapan-tahapan dalam discovery learning memberi stimulus ke siswa untuk berpikir tingkat tinggi. Kemampuan berpikir tingkat tinggi tidak mudah untuk siswa, sehingga perlu dilatih terus. Guru melatih siswa untuk berpikir tingkat tinggi dengan memberikan stimulus berupa pertanyaan yang mengandung Higher Order Thinking Skill (HOTS).

Ilmu Pengetahuan Sosial (IPS) merupakan bagian dari dari kurikulum sekolah yang tanggungjawab utamanya adalah membantu peserta didik dalam mengembangkan pengetahuan, keterampilan, sikap, nilai yang diperlukan untuk 
berpartisipasi dalam kehidupan masyarakat baik di tingkat lokal, nasional maupun global. Dewasa ini IPS hanya dipahami sebagai disiplin ilmu yang mentransfer pengetahuan semata tanpa implementasi dari pengetahuan itu sendiri (Larasati, 2020).

Hal tersebut tidak sesuai dengan keadaan di sekolah. Matapelajaran IPS termasuk pelajaran yang membosankan dan tidak diminati bagi siswa. Pembelajaran IPS selama ini masih teacher center, dimana guru masih menerapkan metode ceramah dan hafalan. Siswa jadi tidak aktif, dan mengantuk ketika pelajaran IPS.

Permasalahan tersebut bertolakbelakang dengan karakter pembelajaran IPS, yang dapat mengembangkan kemampuan berpikir kritis. Materi-materi IPS terdiri dari berbagai fenomena yang terjadi di permukaan bumi, dan berpengaruh terhadap kehidupan manusia serta makhluk hidup lainnya (Larasati, 2017). Materi Pembelajaran IPS menumbuhkan sikap tekun, sehingga siswa tertantang untuk memecahkan masalah yang dihadapi dan berinovasi untuk menemukan hal-hal baru. Menurut (Yudi Cahyo Winoto, 2020) berpikir kritis adalah suatu proses berpikir untuk mengolah pengetahuan yang diperoleh secara terorganisir dengan mengkritisi, memilih, memecahkan masalah, membuat keputusan, mengevaluasi fakta atau asumsi dan/atau logika dengan alasan rasional dan dapat dipertanggungjawabkan.

Berdasarkan hasil wawancara, pada pembelajaran IPS terdapat $60 \%$ siswa merasa bosan di dalam kelas hingga membuat mengantuk dan kelas menjadi gaduh. Siswa tidak minat belajar IPS sebesar 68\%, hal tersebut dikarenakan guru masih menerapkan metode ceramah dan belum menggunakan media pembelajaran. Guru juga masih menerapkan berpikir tingkat rendah atau hafalan, sehingga pembelajarannya kurang bermakna bagi siswa. Guru belum pernah melatih siswa untuk berpikir kritis dalam matapelajaran IPS.

Permasalahan-permasalahan tersebut mendorong untuk melakukan penelitian berjudul "Pengaruh Discovery Learning berbasis Higher Order Thinking Skill terhadap Kemampuan Berpikir Kritis". Dan tujuan penelitian ini untuk mengetahui pengaruh

Discovery Learning berbasis Higher Order Thinking Skill terhadap Kemampuan Berpikir Kritis.

\section{METODE PENELITIAN}

Penelitian ini berjenis Quasi Experiment (eksperimen semu). Non Equivalent Control Group Design dipilih sebagai rancangan penelitian ini. Dua kelas yang memiliki kemampuan sama (homogen) dipilih untuk mewakili kelompok eksperimen dan kontrol.

Populasi penelitian ini adalah kelas $\mathrm{V}$ SDN Banyu Urip IX Surabaya. Penelitian ini diterapkan di matapelajaran IPS materi lingkunganku. Sampel penelitian ini menggunakan teknik purposive sampling. Terpilihlah sampel kelas V-A berjumlah 32 siswa sebagai kelompok eksperimen dengan menerapkan model discovery learning berbasis higher order thinking skill. Kelas V-B berjumlah 30 siswa sebagai kelas kontrol menerapkan model pembelajaran yang biasa 
digunakan guru (penugasan dan diskusi) berbasis higher order thinking order skill.

Penelitian ini menggunakan instrument berupa tes dalam bentuk essai. Tes diujicobakan terlebih dahulu sebelum digunakan penelitian. Ujicoba instrument diperlukan untuk mengetahui validitas, reliabilitas, tingkat kesukaran, dan daya beda. Tes diujikan pada saat sebelum mendapat perlakuan (pretest), dan setelah mendapat perlakuan (posttest). Tes berjumlah 4 essai item soal higher order thinking skill terdiri dari kognitif 4 (Analisis) berjumlah 2 butir soal, kognitif 5 (sintesis) berjumlah 1 butir soal, dan kognitif 6 (evaluasi) berjumlah 1 butir.

Teknik pengumpulan dalam penelitian ini yaitu tes kemampuan berpikir kritis baik berupa pretest dan posttest. Data diperoleh dari tes tesebut dengan penyekoran jawaban terendah diberi nilai 1 , dan tertinggi diberi nilai 4. Gainscore diperoleh dari selisih posttest dengan pretest. Gainscore ini yang akan digunakan untuk pengujian hipotesis. Analisa penelitian ini berupa deskriptif kuantitatif. Penelitian ini menggunakan uji $t$ untuk menghitung analisa datanya dengan bantuan SPSS 22.0 for window. Taraf nilai signifikansi $\alpha=5 \%$.

\section{HASIL DAN PEMBAHASAN Hasil}

Berdasarkan hasil data pretest dan posttest berbasis higher order thinking skill pada kelas kontrol dan eksperimen, dapat dilihat gambar 1 Prosentase Ketercapaian tiap Butir Soal Pretest daan gambar 2. Prosentase Ketercapaian tiap Butir Soal Posttest.

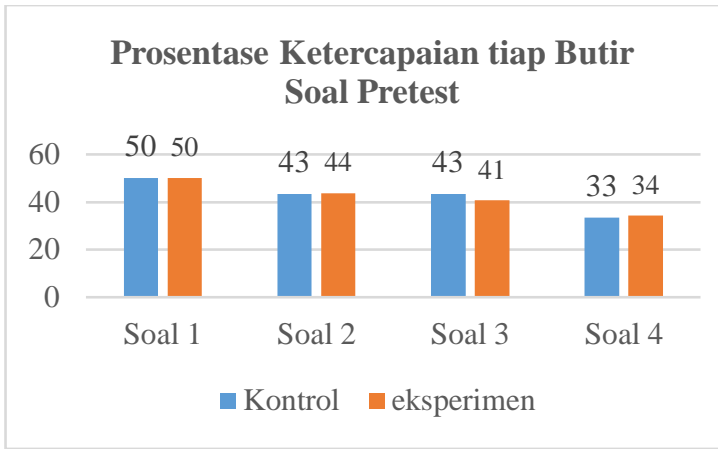

Gambar 1 Prosentase Ketercapaian tiap Butir Soal Pretest

Pada saat pretest, antara kelas kontrol dan eksperimen memiliki prosentase yang hampir sama. Pada soal pertama dengan kognitif analisis (C4) di kelas kontrol sebanyak 15 dari 30 siswa dan kelas eksperimen sebanyak 16 dari 32 siswa yang dapat menjawab dengan benar. Pada soal kedua dengan kognitif analisis (C4) di kelas kontrol sebanyak 13 dari 30 siswa atau $43 \%$ dan kelas eksperimen sebanyak 14 dari 32 siswa atau44\%. Pada soal ketiga dengan kognitif sintesis (C5) siswa yang dapat menjawab dengan benar di kelas kontrol sebanyak 13 dari 30 dan di kelas eksperimen sebanyak 13 dari 32 siswa. Pada soal keempat dengan kognitif evaluasi (C6) semakin turun grafiknya siswa yang bisa menjawab dengan benar. Terbukti di kelas kontrol hanya 10 dari 30 siswa atau sebesar 33\%, dan kelas eksperimen 11 dari 32 siswa atau sebesar $34 \%$.

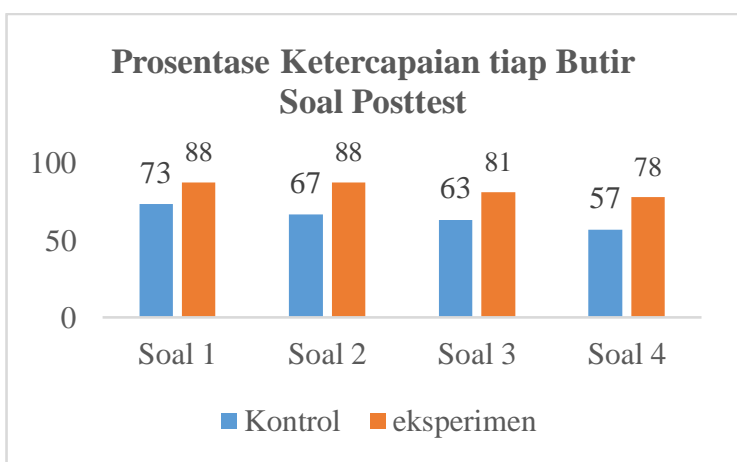

Gambar 2 Prosentase Ketercapaian tiap Butir Soal Posttest 
Berdasarkan prosentase ketercapaian tiap butir soal posstest, kelas kontrol dan eksperimen mengalami peningkatan. Pada soal pertama kelas kontrol mengalami peningkatan sebesar $23 \%$ dari pretest $50 \%$ dan posttest $73 \%$, sedangkan kelas eksperimen meningkat sebesar $38 \%$ dari pretest $50 \%$ dan posttest $88 \%$. Soal kedua kelas kontrol meningkat sebesar $24 \%$, sedangkan eksperimen sebesar 44\%. Soal ketiga kelas kontrol meningkat $20 \%$ dari pretest $43 \%$ dan posttest $63 \%$. Sedangkan kelas eksperimen pretes sebesar $41 \%$ dan posttest sebesar $81 \%$, meningkat sebesar $40 \%$. Pada soal keempat kelas control pretest sebesar 33\% dan posttest sebesar 57\%, meningkat sebesar 24\%. Sedangkan kelas eksperimen meingkat sebesar $44 \%$, dari pretest sebesar $34 \%$ dan posttest sebesar $78 \%$.

Berdasarkan hasil penelitian dianalisis dengan menggunakan uji-t berbantu SPSS 22.0 for window. Hasil analisis uji $\mathrm{t}$ dapat dilihat pada Tabel 1 berikut ini.

Tabel 1 Rangkuman Hasil Analisis Uji-t

\begin{tabular}{lcccccc}
\hline Variabel & N & Mean & T & Df & SD & $\begin{array}{l}\text { Sig. 2 } \\
\text { Ekor }\end{array}$ \\
\hline $\begin{array}{l}\text { Kelas } \\
\text { Eksperimen }\end{array}$ & 32 & 5,75 & 7,878 & 60 & 1,270 & 0,000 \\
$\begin{array}{l}\text { Kelas } \\
\text { Kontrol }\end{array}$ & 30 & 2,60 & 7,878 & 60 & 0,814 & 0,000 \\
\hline
\end{tabular}

Rata-rata gainscore kelas kontrol dan eksperimen selisih sebesar 3,15. Pembelajaran menerapkan model discovery learning rata-rata gainscore lebih tinggi sebesar 5,75, sedangkan pembelajaran menerapkan penugasan dan diskusi sebesar 2,6. Terdapat perbedaan mean kemampuan berpikir kritis antara kelas kontrol dengan eksperimen berdasarkan hasil data yang menggunakan uji-t. Hal ini dapat dilihat dari nilai $t=7,986$ dan signifikansi dua ekor 0,000, sehingga $\mathrm{p}<0,05$.

Berdasarkan hasil analisis data penelitian ekperimen ini menunjukkan bahwa $\mathrm{H}_{0}$ tidak ada pengaruh model discovery learning berbasis higher order thinking skill ditolak. $\mathrm{H}_{1}$ ada pengaruh model discovery learning berbasis higher order thinking skill diterima sebagai hasil penelitian. Dapat disimpulkan bahwa ada perbedaan signifikan kemampuan berpikir kritis antara siswa yang belajar menerapkan model discovery learning berbasis higher order thinking skill dengan model penugasan dan diskusi berbasis higher order thinking skill.

\section{Pembahasan}

Adapun sintaks model discovery learning menurut Syah (dalam Yudi Cahyo Winoto, 2020), yaitu: (1) stimulation atau pemberian rangsangan, (2) problem statement atau identifikasi masalah, (3) data collection atau pengumpulan data, (4) data processing atau pengolahan data, (5) verification atau pembuktian, (6) generalization atau menarik kesimpulan.

Hasil penelitian ini menunjukkan bahwa model discovery learning berbasis higher order thinking skill berpengaruh signifikan terhadap kemampuan berpikir kritis siswa SD. Temuan penelitian ini sejalan dengan penelitian sebelumnya bahwa model discovery learning berbasis higher order thinking skill berpengaruh signifikan terhadap kemampuan berpikir kritis siswa SD dibandingkan dengan pembelajaran konvensional (A. Agustriana, E. 
Ningrum, 2015; PUTRI, 2019; Syiti Mutia Hasnan, Rusdinal, 2020).

Hasil analisis data dari keempat soal esai yang digunakan dalam penelitian ini mengalami peningkatan dibandingkan dengan kemampuan awal. Hal ini menguatkan penelitian sebelumnya bahwa ada perbedaan kemampuan berpikir kritis antara siswa yang dibelajarkan dengan menerapkan discovery learning dan tanpa menerapkan discovery learning (Mawardi, 2020; Yudi Cahyo Winoto, 2020).

Model discovery learning diterapkan dengan beberapa tahapan. Tahapan-tahapan model discovery learning sebagai berikut: 1) stimulus, guru memberikan rangsangan dengan memberikan isu tertentu dalam pembelajarannya. 2) Problem statement, siswa aktif menemukan, menyelidiki, mengidentifikasi atau merumusakan permasalahan-permasalahan dari isu yang diberikan guru. 3) data collecting, siswa mengumpulkan informasi data-data dari berbagai sumber untuk membuktikan kebenaran hipotesis. 4) processing, setelah tahap pengumpulan data kemudian siswa mengolah data-data yang relevan dengan isu yang sudah ditentukan. 5) verification, siswa membuktikan hipotesis yang sudah dirumuskan dengan dibimbing guru. 6) generalization, siswa dapat menarik kesimpulan dari hasil temuannya.

Berdasarkan beberapa tahapan Discovery learning yang paling berpengaruh terhadap kemampuan berpikir kritis siswa SD diduga karena: pertama, siswa aktif selama pembelajaran. Sejalan dengan Kristin (2016)
Kelebihan dalam pembelajaran discovery learning siswa aktif dalam kegiatan belajar.

Guru dalam discovery learning hanya berperan sebagai fasilitator dan pembimbing selama pembelajaran. Guru merancang discovery learning secara efektif supaya pembelajaran berjalan lancar. Siswa dalam discovery learning berperan aktif dari awal sampai akhir kegiatan pembelajaran. Siswa aktif berpikir, melakukan penyelidikan mengumpulkan data, membuktikan hipotesis, dan menarik kesimpulan.

Siswa berlatih berpikir tingkat tinggi, terutama berpikir kritis setelah diberi rangsangan atau stimulus oleh gurunya terkait isu sosial. Stimulus yang diberikan guru berupa pertanyaan-pertanyaan higher order thinking skill tentang isu social, sedangkan siswa aktif berpikir meningkatkan kognitifnya. Model discovery learning merupakan suatu model pembelajaran dimana pendidik tidak banyak memberikan penjelasan namun lebih banyak kepada pengajuan pertanyaan-pertanyaan sehingga peserta didik menjadi lebih aktif dan termotivasi dalam pembelajaran (Syiti Mutia Hasnan, Rusdinal, 2020).

Stimulus yang diberikan guru melatih siswa aktif untuk mengembangkan penalarannya dalam pembelajaran IPS. Hal tersebut sejalan dengan Nurul Istikomah, Stefanus Christian Relmasira (2018) IPS sebagai satu bidang studi yang memiliki tujuan membekali siswa untuk mengembangkan penalarannya di samping aspek nilai dan moral banyak membuat materi sosial dan bersifat hafalan, sehingga pengetahuan dan informasi yang diterima siswa sebatas produk hafalan. 
Siswa aktif secara individu maupun kelompok dalam penerapan discovery learning. Siswa juga aktif bekerja sama dalam mengerjakan tugas kelompok atau diskusi. Hal tersebut membuktikan bahwa siswa diberi ruang untuk melakukan pembelajaran secara langsung. Kedua, siswa mendapat pembelajaran bermakna. Pembelajaran IPS terdapat banyak konsep, hal tersebut menyulitkan siswa untuk mengingatnya dalam jangka waktu yang lama. Discovery learning terdapat tahap Problem statement, siswa melakukan penyelidikan terhadap isu-isu atau stimulus yang diberikan guru.

Penyelidikan yang dilakukan sendiri oleh siswa dapat mempermudah siswa untuk mengingat lebih lama lagi. Sejalan dengan Nurul Istikomah, Stefanus Christian Relmasira (2018) siswa lebih mudah mengingat dan pengetahuan yang diperoleh lebih tahan lama dalam ingatan karena pengetahuan diperoleh dari hasil pemikiran sendiri siswa yang aktif mencari informasi dari permasalahan yang diberikan. Informasi yang didapat dari pengalaman sendiri akan lebih dipahami dan bertahan lama dalam ingatan, sehingga berimplikasi terhadap cara berpikir yang terlihat dari hasil belajar yang diperoleh.

Siswa melakukan penyelidikan dengan percobaan untuk menemukan konsep-konsep atau prinsip-prinsip yang telah dirancang oleh guru dalam bentuk pertanyaan yang disediakan di lembar kerja siswa. Hasil kegiatan percobaan dianalisis dan ditulis dalam lembar kerja siswa. Menurut Kristin (2016) Pembelajaran discovery learning adalah suatu model untuk mengembangkan cara belajar siswa aktif dengan menemukan sendiri, menyelidiki sendiri, maka hasil yang diperoleh akan setia dan tahan lama dalam ingatan, tidak akan mudah dilupakan oleh siswa.

Menemukan sendiri menimbulkan rasa puas, kepuasan batin ini mendorong ingin melakukan penemuan lagi sehingga minat belajarnya meningkat. Penyelidikan menimbulkan kepuasan siswa, apabila hipotesis yang sudah dirumuskan ternyata benar.

Siswa yang membuktikan kebenaran hipotesisnya melalui penyelidikan dapat meningkatkan kepercayaan diri siswa. Siswa lebih percaya diri dan menghargai diri sendiri. Siswa bersemangat melakukan penyelidikan sehingga termotivasi untuk belajar.

Siswa juga merasa senang karena proses pembelajaran memberikan siswa pengalaman secara langsung dalam menemukan pengetahuan. Siswa dapat menemukan pengetahuan baru yang didapat dari hasil penemuan yang dilakukan maupun proses pengidentifikasian. Hal tersebut membuat pembelajaran menjadi berbeda dari biasanya karena siswa juga dilibatkan dalam proses pembelajaran. Kebermaknaan proses pembelajaran akan memudahkan siswa untuk memahami materi yang dipelajarinya (Nanda Estri Wahyuni, Arifin Muslim, 2019).

Penyelidikan ini dilakukan siswa secara langsung baik secara individu maupun kelompok. Menurut Larasati (2017) Penyelidikan secara kelompok berfungsi untuk memutuskan solusi yang tepat dan ilmiah guna memecahkan masalah. Hal tersebut membuat pembelajaran lebih bermakna bagi siswa. 
Ketiga, siswa dapat memecahkan masalah. Kegiatan pembelajaran dalam model discovery learning melibatkan siswa secara maksimal untuk menemukan penyelesaian masalah. Dengan belajar penemuan, anak juga bisa berfikir lebih kritis dan mencoba memecahkan sendiri masalah yang dihadapi (Kristin, 2016).

Siswa mengumpulkan data dari berbagai sumber untuk membuktikan kebenaran hipotesisnya serta memecahkan masalah dengan tepat. Discovery learning sudah mengarahkan siswa untuk pemecahan masalah sehingga dapat melatih siswa untuk berfikir kritis (Nurul Istikomah, Stefanus Christian Relmasira, 2018).

Siswa berpikir kritis maka siswa akan membantu orang lain, menyelesaikan masalah karena pemikiran siswa, serta merupakan jalan keluar terbaik dari masalah yang dihadapi. Sejalan dengan Yudi Cahyo Winoto (2020) model discovery learning adalah suatu rangkaian kegiatan pembelajaran yang melibatkan siswa secara maksimal dengan teknik penemuan untuk mencari dan menyelidiki secara sistematis, kritis, dan logis untuk mencoba memecahkan masalah sendiri yang dihadapi.

Kelemahan dalam penerapan model discovery learning berdasarkan temuan eksperimen dapat dikemukakan: pertama, mengakibatkan alokasi waktu yang tersedia kurang mencukupi untuk terlaksananya seluruh pembelajaran. Kendala yang dihadapi misalnya membutuhkan waktu belajar yang lebih lama dibandingkan dengan belajar menerima.

Mengatasi masalah ini guru hendaknya benar-benar melakukan manajemen waktu secara efektif dan efisien dengan jalan mengontrol setiap tahapan pembelajaran dengan ketat. Guru membimbing dimulai dengan mengajukan beberapa pertanyaan berbasis higher order thinking skill dengan memberikan informasi secara singkat. Pertanyaan dan informasi tersebut dapat dimuat dalam lembar kerja siswa (LKS) yang telah dipersiapkan oleh guru sebelum pembelajaran dimulai.

Kedua, dalam penerapan model discovery learning dibutuhkan guru dengan kemampuan lebih tentang model ini. Kemampuan tersebut dibutuhkan pada sebelum dan saat pembelajaran. Guru merancang pembelajaran Sebelum pelaksanaan pembelajaran harus terlebih dahulu dengan mempersiapkan perangkat-perangkat yang dibutuhkan, seperti lembar ahli/suplemen dan alat evaluasi.

\section{SIMPULAN}

Berdasarkan hasil analisis penelitian ini rata-rata gainscore kelas eksperimen lebih tinggi sebesar 5,75 sedangkan rata-rata gainscore kelas kontrol sebesar 2,6. Nilai $\mathrm{t}=$ 7,986 dan signifikansi dua ekor 0,000, sehingga $\mathrm{p}<0,05$. Hasil penelitian ini menunjukkan bahwa terdapat pengaruh discovery learning berbasis higher order thinking skill terhadap Kemampuan Berpikir Kritis.

Tahapan dalam model discovery learning mendorong siswa untuk berpikir kritis. Hal-hal yang diduga berpengaruh terhadap kemampuan berpikir kritis yaitu siswa aktif, pembelajaran bermakna, dan dapat memecahkan masalah. 


\section{DAFTAR RUJUKAN}

A. Agustriana, E. Ningrum, L. S. (2015). Pengaruh Penggunaan Model Pembelajaran Discovery Learning Terhadap Kemampuan Berpikir Kritis Siswa (Penelitian Quasi Eksperimen di Kelas XI IPS SMA Negeri 1 Dukupuntang). Antologi Pendidikan Geografi, 3(1), 1-16.

Kristin, F. dan D. R. (2016). Pengaruh Penerapan Model Pembelajaran Discovery Learning Terhadap Hasil Belajar Ips Pada Siswa Kelas 4 SD Firosalia. SCHOLARIA, 6(1), 84-92.

Larasati, D. A. (2017). Pengaruh Model Pembelajaran Observasi Lapangan Terhadap Hasil Belajar IPS SD. JURNAL AUTENTIK, 1(1), 1-10. https://doi.org/10.24114/jg.v9i1.6045

Larasati, D. A. (2020). Pengaruh Model Treffinger terhadap Keterampilan Berpikir Kreatif Mahasiswa Pendidikan Guru Sekolah Dasar Donald J Treffinger tahun 1980 memperkenalkan model pembelajaran Treffinger. Model pembelajaran Treffinger dapat melatih belajar kreatif. Hal ini se. Musamus Journal of Primary Education, 2(2), 130-139.

ttps://doi.org/10.35724/musjpe.v2i2.233 1

Mawardi, D. E. P. dan. (2020). Penerapan Model Pembelajaran Inquiry dan Discovery Learning Ditinjau dari Keterampilan Berpikir Kritis. JURNAL BASICEDU, 4(2), 288-294.

Muslihudin, A. (2019). Implementasi Model Discovery Learning Berbantuan Video Dalam Upaya Meningkatkan Hasil Belajar Siswa Kelas V SD Negeri 1 Suganangan. JURNAL ELEMENTARIA EDUKASIA, 2(1), 74-86.

Nanda Estri Wahyuni, Arifin Muslim, P. (2019). Pengaruh Model Discovery Learning Terhadap Sikap Peduli Lingkungan Dan Prestasi Belajar IPA Sekolah Dasar. JURNAL
ELEMENTARIA EDUKASIA, 2(2), 147-153.

Nurul Istikomah, Stefanus Christian Relmasira, A. T. A. H. (2018). Penerapan Model Discovery Learning Pada Pembelajaran Ips Untuk Meningkatkan Keaktifan Dan Hasil Belajar Kognitif Siswa Sekolah Dasar. DIDAKTIKA DWIJA INDRIA, 6(3), 130-139.

PUTRI, W. E. (2019). Pengaruh Model Pembelajaran Discovery Learning Untuk Mencapai Higher Order Thinking Skill Pada Siswa Kelas IV SD Negeri 8 Katon. UNIVERSITAS LAMPUNG.

Sari, M. K. (2014). Pengaruh Media Peta Interaktif Terhadap Pemahaman Dan Hasil Belajar Siswa Pada Mata Pelajaran IPS Kelas IV SD. PREMIERE EDUCANDUm, 4(1), 65-78.

Sore, A. D. (2015). Efektivitas Model Pembelajaran Berbasis Masalah Dalam Mengoptimalkan Keterampilan Berpikir Kritis Dan Hasil Belajar Siswa. VOX EDUKASI, 6(1), 1-15.

Suprihatiningrum, Jamil. (2013). Strategi Pembelajaran: Teori Dan Aplikasi. Yogyakarta: Ar-Ruzz Media.

Syiti Mutia Hasnan, Rusdinal, Y. F. (2020). Pengaruh Penggunaan Model Discovery Learning Dan Motivasi Terhadap Kemampuan Berpikir Kritis Peserta Didik Sekolah Dasar. JURNAL BASICEDU, 4(2), 239-249.

Yudi Cahyo Winoto, T. P. (2020). Efektivitas Model Problem Based Learning Dan Discovery Learning Terhadap Kemampuan Berpikir Kritis Siswa Sekolah Dasar. JURNAL BASICEDU, 4(2), 228-238. 